\title{
PENGARUH WAKTU PEMANGGANGAN TERHADAP KADAR AKRILAMIDA PADA PISANG RAJA ULI (Musa paradisiaca L.)
}

\author{
Devyana Dyah Wulandari*, Uswatun Hasanah \\ Program Studi D-IV Analis Kesehatan, Fakultas Kesehatan, Universitas Nahdlatul Ulama Surabaya, \\ Surabaya, Indonesia \\ *email: devyanadyah@unusa.ac.id
}

Received 24 June 2021

Accepted 25 June 2021

\begin{abstract}
Abstrak
Akrilamida merupakan zat karsinogenik yang terbentuk akibat proses pemanasan suhu tinggi dan kelembaban rendah pada makanan yang kaya akan karbohidrat. Akrilamida paling banyak ditemukan pada produk nabati olahan seperti kentang (kentang goreng dan keripik kentang), serealia (kukis dan roti) serta kopi. Penelitian ini dilakukan bertujuan untuk menganalisis pengaruh waktu pemanggangan terhadap kadar akrilamida pada pisang raja uli (Musa paradisiaca L.). Penetapan kadar akrilamida dilakukan menggunakan metode High Performance Liquid Chromatography (HPLC) pada pisang raja uli yang dipanggang selama 20 menit, 25 menit, dan 30 menit dengan suhu $150^{\circ} \mathrm{C}$. Hasil menunjukkan bahwa kadar akrilamida pada kelompok kontrol (pisang tanpa perlakuan) yaitu sebesar 1,735 ppm, pada pemanggangan sampel pisang selama 20 menit sebesar 1,198 ppm, pada sampel pisang yang dipanggang selama 25 menit sebesar 2,276 ppm, pada sampel pisang yang dipanggang selama 30 menit sebesar 0,917 ppm. Dapat disimpulkan bahwa kadar akrilamida tertinggi terdapat pada pisang raja uli yang dipanggang selama 25 menit dengan nilai signifikansi $P$ sebesar 0,312 yang menunjukkan bahwa tidak terdapat perbedaan yang signifikan antar kelompok perlakuan waktu pemanggangan terhadap kadar akrilamida.
\end{abstract}

Kata kunci: Akrilamida, pisang, reaksi Maillard, pemanggangan

\begin{abstract}
Acrylamide is a carcinogenic substance that is formed due to the heating process at high temperatures and low humidity in foods rich in carbohydrates. Acrylamide is most commonly found in processed plant products such as potatoes (fries and potato chips), cereals (cookies and bread) and coffee. The aim of this research was to analyze the effect of roasting time on the levels of acrylamide in plantain uli (Musa paradisiaca L.). Determination of acrylamide content was carried out using the High Performance Liquid Chromatography (HPLC) method on raja uli banana which was baked for 20 minutes, 25 minutes, and 30 minutes at $150^{\circ} \mathrm{C}$. The results showed that the level of acrylamide in the control group (bananas without treatment) was $1.735 \mathrm{ppm}$, the banana sample baked for 20 minutes was $1.198 \mathrm{ppm}$, the banana sample baked for 25 minutes was $2.276 \mathrm{ppm}$, the banana sample baked for 30 minutes was $0.917 \mathrm{ppm}$. It can be concluded that the highest levels of acrylamide were found in raja uli banana which was roasted for 25 minutes with a $\mathrm{P}$ significance value of 0.312 which indicated that there was no significant difference between the treatment groups of roasting time on acrylamide levels.
\end{abstract}

Keywords: Acrylamide, banana, Maillard reaction, roasting 


\section{Pendahuluan}

Akrilamida atau 2-propenamida adalah padatan kristalin yang tidak berbau dan tidak memiliki warna. Rumus molekul akrilamida ialah $\mathrm{C}_{3} \mathrm{H}_{5} \mathrm{NO} \quad\left(\mathrm{CH}_{2}=\right.$ $\mathrm{CHCONH}_{2}$ ) dengan berat molekul 71,079 $\mathrm{g} / \mathrm{mol}$. Sifat akrilamida sulit larut dalam air, lebih sulit menguap di udara, dan senyawa ini memiliki titik didih $125^{\circ} \mathrm{C}$. Akrilamida adalah senyawa kimia yang biasa digunakan industri purifikasi air, tanah, kemasan, dan penelitian ilmiah seperti elektroforesis; kromatografi; serta mikroskop elektron. Senyawa akrilamida diketahui memiliki neurotoksik yang dapat menyerang manusia, sedangkan genotoksik dan karsinogenik pada hewan. Akrilamida merupakan crystalline amide yang terpolimerisasi dengan cepat dan dapat terbentuk selama proses pemanasan makanan yang mengandung pati dalam temperatur tinggi. Akrilamida juga sering ditemukan pada asap rokok, asap industri seperti indutri plastik. Akrilamida dapat ditemukan pada kondisi udara yang lembab (Harimadi, et al., 2018).

Akrilamida terbentuk terutama dalam makanan yang kaya karbohidrat melalui reaksi Maillard yang terjadi antara karbohidrat pereduksi (glukosa, fruktosa, dll) dan asam amino (terutama asparagin). Reaksi bertanggung jawab untuk pembentukan rasa dan warna tertentu (kecoklatan saat proses penggorengan) (Sarion, 2021). Dalam penelitian ini variabel pemanasan yang dipilih adalah pemanggangan, hal ini dikarenakan banyaknya olahan makanan terutama pada pisang yang diproses dengan cara di panggang. Proses pemanggangan juga akan mempermudah pengukuran kadar akrilamida dimana tidak akan ada kontaminasi senyawa akrilamida dari bahan makanan yang lainnya, seperti minyak, mentega dan semacamnya. Sehingga kadar akrilamida yang didapat murni hanya dari sampel pisang.

Salah satu makanan yang mengandung karbohidrat dan protein yang tinggi adalah pisang. Pisang merupakan makanan yang dikelompokkan dalam buah-buahan yang mempunyai kandungan gizi yang tinggi. Kandungan yang ada pada buah pisang adalah karbohidrat, protein, lemak, mineral, dan mengandung vitamin C. pisang yang digunakan dalam penelitian ini adalah jenis pisang raja uli (Musa paradisiaca L.). Pisang raja uli (Musa paradisiaca L.) merupakan pisang yang sering digunakan sebagai bahan olahan makanan karena memiliki rasa yang sangat manis dan memiliki bau yang khas, sehingga cocok digunakan sabagai olahan makanan seperti makanan penutup atau makanan yang lainnya. Pengolahan makanan yang mengandung karbohidrat seperti pisang dengan suhu tinggi di hipotesiskan akan memicu terbentuknya senyawa akrilamida. Pembentukan akrilamida diinisiasi oleh suhu pemanasan yang tinggi, sesuai dengan persamaan Arrhenius bahwa reaksi kimia yang dipengaruhi oleh suhu dinyatakan sebagai energi aktivasi (Ea). Semakin tinggi Ea, laju reaksi akan semakin dipengaruhi oleh suhu. Ea untuk reaksi Maillard berbanding lurus dengan pembentukan akrilamida yaitu sebesar 10-160 kJ/mol. Telah dilaporkan sebelumnya bahwa durasi waktu merupakan faktor utama yang mempengaruhi peningkatan kadar akrilamida pada suhu tinggi. (Perera, 2021). Senyawa akrimida dapat memicu kanker yang dapat menyebabkan terjadi kerusakan pada sistem syaraf (Aminah \& Isworo, 2010).

Pada penelitian sebelumnya yang dilakukan oleh Debora Tandi, Fatimawali dan Frenly Wehantouw (2012) olahan makanan yang diteliti adalah pisang goreng dimana penelitian tersebut menghitung kadar akrilamida dalam sampel. Penelitian tersebut menggunakan 12 sampel pisang goreng yang berasal dari 12 tempat penjualan dikota Manado. Hasil yang didapatkan pada sampel pisang goreng ialah dengan waktu rambatnya 
sebesar $\pm 4,284$ menit dan kadar akrilamida yang terkandung dalam pisang goreng sekitar 39,65-1789,52 $\mu \mathrm{g} / \mathrm{kg}$. Hasil yang diperoleh terbilang aman untuk dikonsumsi karena masih berada dibawah ambang batas.

Berdasarkan uraian di atas maka penelitian ini dilakukan bertujuan untuk menganalisis kadar akrilamida pada pisang yang proses pemanggangannya dengan waktu yang berbeda-beda. Penelitian ini dilakukan menggunakan metode High Performance Liquid Chromatography (HPLC).

\section{Metode Penelitian}

Alat dan Bahan

Alat yang digunakan pada penelitian ini adalah pisau, oven, Kromatografi Cair Kinerja Tinggi (KCKT), labu ukur, pipet ukur, pipet volume, spatula, neraca analitik, saringan whattman nomor 1 , pengaduk ultrasonik, corong pisah, beaker glass, stirrer, botol aquadest, penangas air, dan sentrifuse. Bahan yang digunakan pada penelitian ini adalah pisang raja uli, asetonitril digunakan untuk fase gerak, aquadest sebagai pelarut fase gerak, asam fosfat $85 \%$, standar akrilamida, diklorometan digunakan untuk mencuci sampel, etanol dan seton.

\section{Preparasi sampel}

Sampel pisang raja uli yang digunakan adalah pisang dengan kondisi yang sudah matang kemudian buah pisang dibersihkan dan dipisahkan antara daging dan kulitnya. Selanjutnya buah pisang dipanggang menggunakan oven dengan suhu $150^{\circ} \mathrm{C}$. Waktu yang dibutuhkan untuk memanggang berbeda-beda dimana sampel satu dipanggang selama 20 menit, sampel dua dipanggang selama 25 menit, dan sampel tiga dipanggang selama 30 menit (Hermanto \& Adawiyah, 2010).

\section{Pembuatan larutan standar akrilamida}

Padatan standar akrilamida ditimbang kemudian dilarutkan kedalam fase gerak (Asetonitril:Aquadest) sebanyak $100 \mathrm{ml}$, lalu homogenkan larutan sampai tercampur rata. Larutan akrilamida yang memiliki konsentrasi 20 ppm (mg/L) dipipet dan dimasukkan kedalam abu ukur $10 \mathrm{ml}$. Tabung pertama larutan induk di pipet sebanyak $0.5 \mathrm{ml}$, tabung kedua $1 \mathrm{ml}$, tanung ketiga $1.5 \mathrm{ml}$ dan tabung keempat 2 ml. Kemudian keempat tabung di tambahkan dengan larutan fase gerak sampai tanda batas sehingga mendapatkan konsentrasi $0.1 \mathrm{ppm}, 0.2 \mathrm{ppm}, 0.3 \mathrm{ppm}$, dan 0.4 ppm. Selanjutnya keempat larutan yang memiliki konsentrasi berbeda di analisis menggunakan HPLC. Larutan standar disuntikkan sebanyak $50 \quad \mu 1$ kedalam kolom HPLC (Hermanto \& Adawiyah, 2010).

\section{Penetapan kadar akrilamida}

Sampel pisang raja uli yang telah melewati tahap preparasi sampel kemudian dihaluskan dan ditimbang sebanyak 10 gr. Kemudian sampel dilarutkan dengan $50 \mathrm{ml}$ larutan diklorometan dan ditambahkan dengan 5 ml larutan etanol. Selanjutnya sampel ditambahkan kembali dengan larutan diklorometan sebanyak $50 \mathrm{ml}$. Lalu dihomogenkan dengan menggunakan stirrer selama 2 jam. Larutan sampel disentrifugasi dengan kecepatan $3500 \mathrm{rpm}$ selama 20 menit pada suhu $15^{\circ} \mathrm{C}$. kemudian supernatan di buang dan endapan dikerigkan didalam oven dengan suhu $40^{\circ} \mathrm{C}$. Endapan yang didapatkan kemudian ditambahkan dengan $20 \mathrm{ml}$ aseton. Selanjutnya endapat di aduk menggunakan stirrer selama 30 menit. Lalu sampel dimasukkan kedalam penangas air dengan suhu $40^{\circ} \mathrm{C}$ selama 20 menit. Kemudian sampel di setrifugasi kembali dengan kecepatan $3000 \mathrm{rpm}$ selama 20 menit pada suhu $15^{\circ} \mathrm{C}$. sampel yang telah di sentrifugasi kemudian disaring menggunakan kertas saring whattman nomor 1. Selanjutnya filtrat diuapkan menggunakan evaporator sampai kering. Endapan yang menempel di tabung evaporator di cuci menggunakan 
fase gerak sebanyak $2 \mathrm{ml}$. Lalu larutan sampel di saring atau dimembran menggunakan syringe dan dipindahkan ke labu takar $5 \mathrm{ml}$. Kemudian larutan sampel di ambil sebanyak $50 \mu$ l menggunakan microliter syringe dan diinjeksikan kedalam kolom HPLC (Muthaiah, et al., 2019).

\section{Hasil dan Pembahasan}

Sampel yang digunakan dalam penelitian ini adalah sampel pisang jenis pisang raja uli (Musa paradisiaca L.) yang di jual di pasar tradisional Surabaya. Sampel pisang raja uli (Musa paradisiaca L.) diberikan perlakuan dengan cara dipanggang selama 20 menit, 25 menit dan 30 menit.

\section{Penentuan kurva standar}

Kurva standar digunakan untuk menentukan persamaan garis liner yang akan dipakai untuk menentukan kadar akrilamida pada sampel. Pembuatan larutan satandar menggunakan bubuk standar akrilamida yang dilarutkan menggunakan fase gerak. Larutan standar akrilamida dibuat dengan konsentrasi yang beragam yaitu, $0.1 \mathrm{ppm}, 0.2 \mathrm{ppm}$, 0.4 ppm, 1 ppm, dan 2 ppm.

Tabel 1. Standar Akrilamida

\begin{tabular}{|c|c|c|}
\hline $\begin{array}{c}\text { Konsentrasi } \\
(\mathrm{ppm})\end{array}$ & $\begin{array}{c}\text { tR } \\
(\mathrm{min})\end{array}$ & Area \\
\hline 0.1 & 8.025 & 54735 \\
\hline 0.2 & 8.050 & 75446 \\
\hline 0.4 & 8.100 & 174782 \\
\hline 1 & 8.008 & 377140 \\
\hline 2 & 8.033 & 644708 \\
\hline
\end{tabular}

Pada Tabel 1 didapatkan hasil penentuan standar akrilamida yaitu, untuk konsentrasi 0.1 ppm dimana waktu retensinya selama 8.025 menit dengan luas area 54735, konsentrasi $0.2 \mathrm{ppm}$ waktu retensinya selama 8.050 menit dengan luas area 75446, konsentrasi 0.4 ppm selama 8.100 menit dengan luas area
174782, pada konsentrasi 1 ppm selama 8.008 menit dengan luas area 377140, dan konsentrasi 2 ppm waktu retensi yang dibutuhkan selama 8.033 dengan luas area 644708

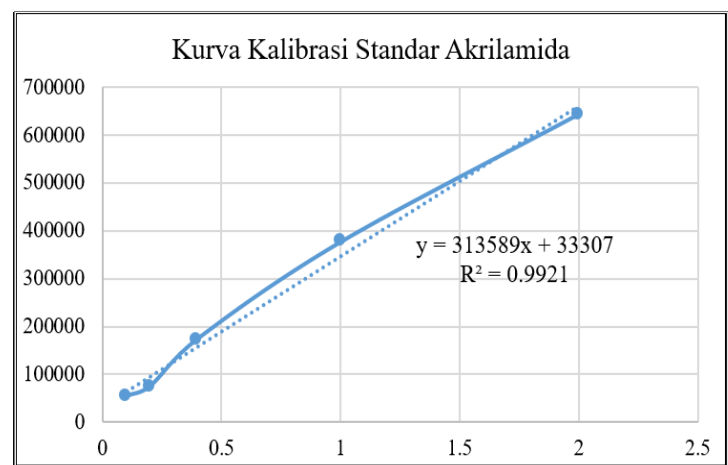

Gambar 1. Kurva Kalibrasi Standar Akrilamida

Gambar 1 adalah kurva kalibrasi standar akrilamida dimana Persamaan garis yang terbetuk adalah $\mathrm{Y}=313589 \mathrm{X}$ +33307 dengan nilai $\mathrm{R}^{2}=0.9921$. Berdasarkan persamaan kurva yang diperoleh maka kadar akrilamida pada sampel dapat dihitung dengan cara subtitusi luas area sampel pada nilai $\mathrm{Y}$ pada persamaan kurva.

\section{Kadar akrilamida pada sampel}

Kadar akrilamida pada sampel akan diukur setelah sampel pisang diberikan perlakuan sesuai dengan masing masing kelompok. Pada penelitian ini dibagi menjadi 4 kelompok. Kelompok kontrol adalah kelompok dimana sampel pisang tidak diberikan perlakuan. Kelompok kedua ialah sampel pisang diberi perlakuan pemanggangan selama 20 menit. Kelompok ketiga sampel pisang diberikan perlakuan pemanggangan selama 25 menit. Kelompok keempat sampel pisang duberikan perlakuan pemanggangan selama 30 menit. Kemudian masing masing sampel diukur kadar akrilamidanya menggunakan alat HPLC. Hasil kadar akrilamida ditunjukkan pada Tabel 2. 
Tabel 2. Hasil Kadar Akrilamida

\begin{tabular}{|c|c|c|c|c|}
\hline \multirow{2}{*}{ Sampel } & \multicolumn{3}{|c|}{ Akrilamida } & Rerata \\
\cline { 2 - 4 } & tR(min) & Area & ppm & ppm \\
\hline \multirow{3}{*}{ Kontrol } & 8.133 & 723241 & 2,2001 & \multirow{3}{*}{1,735} \\
\cline { 2 - 4 } & 8.100 & 757978 & 2,3109 & \\
\cline { 2 - 4 } & 8.075 & 250589 & 0,6929 & \\
\hline \multirow{3}{*}{ Waktu } & 8.075 & 596418 & 1,7957 & \multirow{3}{*}{1,198} \\
\cline { 2 - 4 } menit & 8.067 & 325537 & 0,9319 & \\
\cline { 2 - 4 } & 8.058 & 305155 & 0,8669 & \\
\hline \multirow{3}{*}{ Waktu } & 8.092 & 1179339 & 3,6546 & \multirow{3}{*}{2,276} \\
\cline { 2 - 4 } menit & 8.025 & 587530 & 1,7674 & \\
\cline { 2 - 4 } & 8.008 & 474238 & 1,4061 & \\
\hline Waktu & 7.967 & 202167 & 0,5385 & \multirow{3}{*}{0,917} \\
\cline { 2 - 4 } 30 menit & 7.967 & 170543 & 0,4376 & \\
\cline { 2 - 4 } & 8.100 & 589783 & 1,7745 & \\
\hline
\end{tabular}

Pada tabel 2 dapat diamati jika waktu retensi pada sampel mendekati waktu retensi yang terjadi pada standar akrilamida. Untuk hasil kadar akrilamida pada kontrol yaitu 1,735 ppm. Hasil kadar akrilamida pada pemanggangan sampel pisang selama 20 menit yaitu 1,198 ppm. Hasil kadar akrilamida pada sampel pisang yang dipanggang selama 25 menit adalah 2,276 ppm. Kadar akrilamida dari sampel pisang yang dipanggang selama 30 menit ialah 0,917 ppm. Pada tabel dapat diamati hasil akrilamida yang terbentuk pada setiap kelompok tidak stabil, kadar akrilamida paling rendah ialah pada kelompok pemanggangan pisang selama 30 menit dan kadar akrilamida paling tinggi adalah pada kelompok pemanggangan selama 25 menit.

Berdasarkan hasil analisis statistik menggunakan uji ANOVA satu arah menunjukkan hasil nilai signifikansi $\mathrm{P}$ sebesar 0,312 yang berarti bahwa tidak terdapat perbedaan signifikan antar kelompok perlakuan.

Akrilamida $\quad\left(\mathrm{CH}_{2}=\mathrm{CH}-\mathrm{CO}-\mathrm{NH}_{2}\right)$ merupakan molekul senyawa organik yang tersusun atas karbon (50.69\%), hidrogen $(7.09 \%)$, nitrogen $(19.71 \%)$, and oksigen $(22.51 \%)$, dengan berat molekul sebesar $71.08 \mathrm{~g}$. Akrilamida akan mudah terbentuk jika bahan makanan memiliki kandungan pati atau karbohidrat yang tinggi melalui proses penggorengan atau pemanggangan (Ubaoji, 2016). Pisang raja uli diketahui mengandung kadar karbohidrat sebesar 38,2 gram dalam 100 gram daging buah (Direktorat Gizi, 1977 dalam Lestari, 2017). Akrilamida terbentuk dari reaksi Maillard yang terjadi antara karbonil seperti fruktosa (komponen sukrosa terhidrolisis), dan glioksal yang terbentuk dari glukosa, dengan adanya asparagin pada suhu sekitar $323,15 \mathrm{~K}$ selama proses pemanasan (Gil, 2020).

Tahapan pembentukan akrilamida dimulai dari reaksi adisi yang dihasilkan dari serangan nukleofilik gugus amino asparagin pada gugus aldo atau keto dari glukosa dan fruktosa, menghasilkan senyawa perantara pertama (INT I ). Langkah kedua adalah eliminasi air di mana atom hidrogen $(\beta)$ dari $\mathrm{NH}$ yang ada dalam zat antara pertama bermigrasi ke atom oksigen dari gugus hidroksil berikutnya (senyawa perantara kedua-INT II). Tahap tersebut merupakan tahap dekarboksilasi dengan eliminasi Syn yang menyebabkan hilangnya $\mathrm{CO}_{2}$ dan pembentukan zat antara ketiga (INT III). Tahap selanjutnya adalah tahap hidrolisis yang terjadi dalam dua langkah. Reaksi adisi molekul air (tahap IV) dengan ikatan rangkap yang terbentuk antara $\mathrm{N}$ dan $\mathrm{C}$ akan mengalami penataan ulang (rearrangement) dan pemutusan ikatan pada zat antara keempat (INT IV). Pecahnya zat ini yang menyebabkan terjadinya pembentukan akrilamida dan produk sampingan yang berbeda tergantung gula prekursornya, jika berasal dari fruktosa maka hasil sampingnya adalah adalah (2,3,4,5-tetrahidroksi asam pentanoat) dan jika berasal dari glioksal (dari glukosa) maka produk sampingnya adalah adalah (3,4,5,6-tetrahidroksi-2okso-7-heksanal) (Michalak, 2020). Tahapan pembentukan akrilamid dapat dilihat pada Gambar 2.

Berdasarkan hasil yang tercantum pada Tabel 2 dapat diketahui bahwa kadar akrilamida tertinggi ditemukan pada proses pemanggangan selama 25 menit yaitu sebesar 2,276 ppm, namun terjadi penurunan pada proses pemanggangan 
selama 30 menit yaitu sebesar $0,917 \mathrm{ppm}$. Berdasarkan penelitian yang dilakukan oleh (Guillen, 2017) mengemukakan bahwa suhu yang terlalu tinggi dan pemanasan yang lama dapat mengakibat terjadinya proses degradasi akrilamida sehingga pada penelitian ini ditemukan penurunan kadar akrilamida pada proses pemanggangan selama 30 menit. Selain itu, pemanasan dalam jangka waktu yang lama juga dapat menyebabkan degradasi komponen nutritif seperti karbohidrat, yang berakibat terjadi penurunan kadar akrilamid pada proses pemanggangan selama 30 menit. Namun secara statistik tidak terdapat perbedaan yang signifikan pada tiap kelompok perlakuan. Hal ini dapat disebabkan karena ada faktor lain yang mempengaruhi kadar akrilamida dalam suatu bahan makanan yaitu suhu pemanggangan, dan komposisi karbohidrat yang terdapat didalam bahan makanan (Hermanto, 2010).

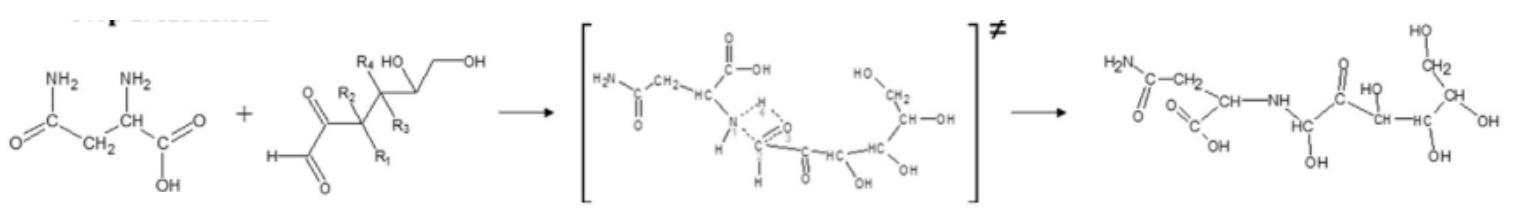

Asparagin

TS1

INT1

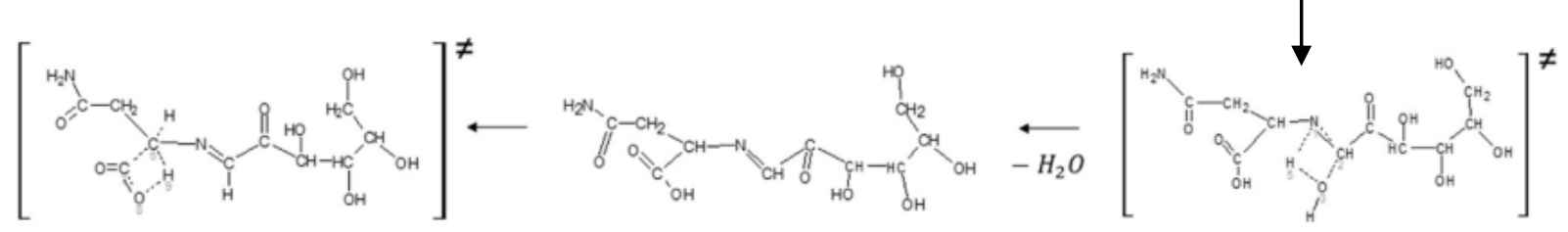

TS3

INT2

TS2<smiles>C=CC(N)=O</smiles>

Gambar 2. Mekanisme Pembentukan Akrilamida dari Reaksi antara Asparagin dan Glioksal dari Glukosa

\section{Kesimpulan}

Berdasarkan hasil penelitian diatas, dapat disimpulkan bahwa tidak terdapat perbedaan yang signifikan antar kelompok perlakuan waktu pemanggangan terhadap kadar akrilamida. Namun berdasarkan hasil yang diperoleh secara deskriptif diketahui bahwa peningkatan kadar akrilamida terdapat pada kelompok perlakuan waktu pemanggangan 25 menit dan akan menurun pada waktu pemanggangan 30 menit. Hal ini dapat disebabkan karena telah terjadi penurunan kandungan karbohidrat dan terjadinya proses degradasi akrilamida pada waktu pemanggangan yang terlalu lama. 


\section{Daftar Pustaka}

Aminah, S. \& Isworo, J. T. (2010). Analisis Akrilamida pada Kripik dan Kudapan Goreng dari Umbi-Umbian. Prosiding seminar nasional unimus, 256-260.

Gil, M. et all. (2020). Effect of temperature on the formation of acrylamide in cocoa beans duringdrying treatment: An experimental and computational study. Heliyon, 6.

Guillen, S., Oria, R., Salvador, M.R., Martorell, I., Corrales, A., and K.Granby. (2017). Effectiveness Of A Temperature Control System In Home Induction Hobs To Reduce Acrylamide Formationduring Pan Frying. Ital. J. Food Sci., 29.

Harimadi, K. J., M., Kiyat, W. E. \& Budijanto, S. (2018). Potensi Pemanfaatan Asparaginase untuk Mengurangi Kadar Akrilamida pada Keripik Kentang dan Singkong. Pangan, 1, 67-78.

Hermanto, S., Adawiyah R. (2010). Analisis Kadar Akrilamida Dalam Sediaan Roti Kering Secara KCKT. Valensi, 2(1), 354-361.

Lestari , H. D. (2017). Aktivitas Antioksidan dan Uji Organoleptik Minuman Herbal Kulit Pisang Raja Bulu (Musa paradisiaca L. var sapientum) pada Suhu Pengeringan Berbeda sebagai Sumber Belajar Bilogi. Malang: Universitas Muhammadiyah Malang.

Michalak, J, Kujawska, M.C., Klepacka, J., and Elzbieta Gujska. (2020). Effect of Microwave Heating on the
Acrylamide Formation in Foods. Molecules, $\quad 25, \quad 4140$; doi:10.3390/molecules25184140.

Muthaiah, P.M., Govindaswamy, A., Semwal A.D., Sharma, G.K. (2019). HPLC-UV Quantitative Analysis of Acrylamide in Snack Foods of India. Defence Life Science Journal, 4(1). DOI : $10.14429 / \mathrm{dlsj} .4 .12190$.

Perera, D.N., Hewavitharana, G.G., and S.B. Navaratne. (2021). Comprehensive Study on the Acrylamide Content of High Thermally Processed Foods. BioMed Research International, Article ID 6258508, 13 pages. https://doi.org/10.1155/2021/625850 8.

Sarion, C., Codin, G.G. Dabija, A. Acrylamide in Bakery Products: A Review on Health Risks, Legal Regulations and Strategies to Reduce Its Formation. Int. J. Environ. Res. Public Health, 18, 4332. https://doi.org/10.3390 /ijerph18084332.

Tandi, D, Fatimawali dan Frenly Wehantouw. (2012). Analisis Kandungan Akrilamida Dalam Pisang Goreng Yang Beredar di Kota Manado Menggunakan Kromatografi Cair Kinerja Tinggi (KCKT). Pharmacon, 1(2).

Ubaoji , K. I. \& Orji, V. U. (2016). A Review On Acrylamide In Foods: Sources And Implications To Health. Journal of African Studies, $6,01-17$. 